\title{
Significant Relationship between Overweight and Hypertension in the Elderly
}

\author{
Suwanda Wahyudin, ${ }^{1}$ Rudolf Andean, ${ }^{2}$ Lilik Sukesi ${ }^{3}$ \\ ${ }^{1}$ Faculty of Medicine Universitas Padjadjaran, Indonesia, ${ }^{2}$ Departement of Biomedical Sciences \\ Faculty of Medicine Universitas Padjadjaran, Indonesia, ${ }^{3}$ Department of Internal Medicine Faculty \\ of Medicine Universitas Padjadjaran/Dr. Hasan Sadikin General Hospital Bandung, Indonesia
}

\section{Abstract}

Background: Hypertension is one of the degenerative diseases that commonly occurs in the elderly, however, the etiology is still unclear. One of the risk factors is overweight. This study aimed to investigate the relationship between overweight and hypertension in the elderly living in Hegarmanah village.

Methods: A cross-sectional analytic study was conducted from September to November 2013, including 100 elderly in Hegarmanah village Jatinangor, Sumedang, using a cluster sample technique. The data of body weight, height, and blood pressure were obtained after informed consent.

Results: In total, 58 females and 42 males were included. The nutritional status was underweight (9\%), normal (45\%), overweight (31\%), and obese (15\%). Hypertension among the elderly was normal (4\%), prehypertension stage 1 (18\%), hypertension stage II (24\%), and hypertension stage III (54\%). The hypertension was occurred in $43.6 \%$ non-overweight group and $56.4 \%$ in the overweight group, resulting in a significant relationship between overweight and hypertension in the elderly $(\mathrm{p}=0.001)$. Conclusions: The high prevalence of hypertension among the elderly who were overweight suggests a better promotion in lifestyle control, a particularly nutritional program for the elderly to manage hypertension and its complication.

Keywords: Elderly, hypertension, lifestyle, overweight

\section{Introduction}

The prevalence of hypertension in Indonesia is reported around $50 \%$ for the age group of 45-64 years old and 65\% age group of above 65 years old. ${ }^{1}$ The primary hypertension cases are predominantly about $90-95 \%$ in the elderly, however, the etiology is still unknown. ${ }^{2}$

Untreated hypertension may cause complications, including congestive heart failure, angina pectoris, encephalopathy, stroke, proteinuria, and renal impairment. ${ }^{3}$ One of the risk factors for hypertension is overweight. ${ }^{4}$ Overweight is an excessive accumulation of fat in adipose tissue. The risk of hypertension in Indonesia is increased by 2.15 fold in the overweight group compared with the underweight group. ${ }^{4}$ Individuals who have a $20 \%$ increased of normal weight have a risk of hypertension 3-8 times higher compared to individuals with normal weight. ${ }^{5}$ The aim of this study was to investigate the relationship between overweight and hypertension in the elderly living in Hegarmanah village.

\section{Methods}

The study design was an analytic study with a cross-sectional approach, conducted from September to November 2013 in Hegarmanah village, Jatinangor, Sumedang. The study included 100 elderly above 60 years old, selected by cluster sample technique. The exclusion criteria were elderly who could not sit on a chair and/or stood up when the examination was performed. After approving informed consent, body weight, height, and blood pressure were measured.

The measurement of body weight was performed with a calibrated scale with a

Correspondence: Suwanda Wahyudin, Faculty of Medicine, Universitas Padjadjaran, Jalan Raya Bandung-Sumedang Km. 21, Jatinangor, Sumedang, Indonesia, E-mail: suwandafkup2010@gmail.com 
capacity of $120 \mathrm{~kg}$ and an accuracy rate of 0.5 $\mathrm{kg}$. Height measurement was performed with a calibrated microtoise with the maximal length was $200 \mathrm{~cm}$ and the accuracy rate was 0.5 $\mathrm{cm}$. Body mass index (BMI) was calculated by dividing body weight $(\mathrm{kg})$ by squared height $\left(\mathrm{m}^{2}\right)$. The BMI was designated as underweight (<18.5), normal (18.5-24.9), overweight (2529.9) and obesity ( $>30)$.

Blood pressure measurement was performed by using a sphygmomanometer (mmHg) and a stethoscope. The respondents were asked to sit on a chair and relaxed before blood pressure measurement was taken twice. The second measurement was performed to finalize the result of blood pressure. There were four stages of high blood pressure or hypertension: stage I or prehypertension was $120 / 80$ to $139 / 89$; stage II or mild hypertension was $140 / 90$ to $159 / 99$ and stage III or moderate hypertension was 160/100 to 179/109.

This study was approved by the Health Research Ethics Committee Faculty of Medicine, Universitas Padjadjaran. Analysis of data was performed using a chi-square test. The results of $\mathrm{p}$-value showed statistically significant if less than $0.05(\mathrm{p}<0.05)$, using Software Statistical Product and Service Solution (SPSS) v. 15.0

\section{Results}

In total, females (58\%) had participated in the study and most of them $(87 \%)$ were in 60-74 age groups. The overweight elderly groups (BMI $\geq 25 \mathrm{~kg} / \mathrm{m}$ ) were found in $46 \%$ of subjects, including obese (15\%) and overweight (31\%). Hypertension cases were detected $78 \%$, including hypertension stage 2 or mild hypertension (24\%) and hypertension stage 3 or moderate hypertension (54\%) as shown in Table 1.

In the non-overweight elderly group, $43.6 \%$ of hypertension cases were found. The Chi-square test showed that there was a significant relationship between overweight and hypertension $(\mathrm{p}=0.001)$ with OR 12 (Table 2).

Table 1 Characteristics of Elderly living in Hegarmanah, Bandung

\begin{tabular}{lcc}
\hline \multicolumn{1}{c}{ Variable } & N & Percentage (\%) \\
\hline Age; years old & & \\
$60-74$ & 87 & 87 \\
$75-89$ & 11 & 11 \\
$\geq 90$ & 2 & 2 \\
Gender & & \\
Female & 58 & 58 \\
Male & 42 & 42 \\
Nutritional status & & \\
Underweight & 9 & 9 \\
Normal & 45 & 45 \\
Overweight & 31 & 31 \\
Obese & 15 & 15 \\
Hypertension & & \\
Normal & 4 & 4 \\
Stage I prehypertension & 18 & 18 \\
Stage II mild hypertension & 24 & 24 \\
Stage III moderate hypertension & 54 & 54 \\
\hline Note: The nutritional status was designated as underweight (BMI <18.5), normal (BMI 18.5-24.9), overweight (BMI \\
25-29.9) and obesity (BMI > 30). The hypertension was classified as stage 1 or prehypertension (120/80 to 139/89); \\
stage 2 or mild hypertension (140/90 to 159/99) and stage 3 or moderate hypertension (160/100 to 179/109). \\
$\quad$ & \\
& &
\end{tabular}


Table 2 The Relationship Between Overweight and Hypertension

\begin{tabular}{lccccc}
\hline \multirow{2}{*}{ Nutritional Status } & \multicolumn{5}{c}{ Blood Pressure } \\
\cline { 2 - 4 } & \multicolumn{2}{c}{ Non-hypertension } & \multicolumn{2}{c}{ Hypertension } & p-value \\
\cline { 2 - 4 } & $\mathrm{N}$ & $\%$ & $\mathrm{~N}$ & $\%$ & 0.001 \\
\hline Non-Overweight (BMI<25) & 20 & 90.9 & 34 & 43.6 & \\
Overweight (BMI $\geq 25)$ & 2 & 9.1 & 44 & 56.4 & \\
Total & 22 & 100 & 78 & 100 \\
\hline
\end{tabular}

Note: Non-hypertension designated as Normal \& Prehypertension or stage I; Hypertension designated as Stage II \& III

\section{Discussion}

In this study, most of the elderly livings in Hegarmanah Village have been found to have hypertension; with hypertension stage III is being the most prevalent. Previous studies have shown that the prevalence of hypertension in Indonesia is $32.2 \%$ and particularly in West Java is $29.4 \%$, although in the general population of Indonesia $76 \%$ is undiagnosed. ${ }^{4}$ The result in this study has detected higher hypertension cases in Hegarmanah elderly. It might occur because of undiagnosed hypertension which is not reported to Jatinangor Primary Health Care Center or Puskesmas. The aging itself contribute to hypertension state which is caused by blood vessel damage, increasing smooth muscle cells, collagen deposit, and decreasing elastin, causing narrowed lumen and rigid blood vessel. ${ }^{6}$

In our study, $43.6 \%$ of hypertension cases are found in the non-overweight elderly group. This phenomenon could be explained by factors of blood pressure in the normal weight elderly, including monounsaturated fatty acid, saturated fatty acid, sodium intake, plasma total cholesterol level, the ratio of total cholesterol to High Dense Lipoprotein (HDL)-cholesterol and a sports index. ${ }^{7}$ In the other hand, the hypertension cases in the overweight elderly group could be influenced by some factors, including potassium intake, calcium intake, BMI score. Furthermore, there are other risk factors of hypertension such as age, sex, family history, sodium intake, diabetes mellitus, obesity, smoking habit, alcohol and caffeine consumption, potassium intake, calcium intake, low magnesium, and stress. ${ }^{4}$ All of these risk factors may play a significant role as confounding factors that should be evaluated further.

The pathophysiology of overweight related to hypertension might be due to the role of leptin, produced by adipose tissue. Leptin increases the production of catecholamine to stimulate a sympathetic nerve in the blood vessels, causing an increased total peripheral resistance (TPR). Leptin indirectly increases cardiac output (CO), and both play an important role in blood pressure. Therefore, leptin, which is over secreted in adipose tissue of overweight individuals could elevate arterial blood pressure. ${ }^{8,9}$

Our study has shown a significant relationship between BMI and blood pressure. BMI $\geq 22 \mathrm{~kg} / \mathrm{m}^{2}$ may increase the risk of hypertension. The optimal BMI for a female is $24.1 \mathrm{~kg} / \mathrm{m}^{2}$ and for a male is $23.8 \mathrm{~kg} / \mathrm{m}^{2}$. The risk of hypertension in individuals of normaltension increased with an increase in body weight. ${ }^{10}$

Limitation of the study is that data of risk factors that may play a significant role in hypertension and serve as confounding factors such as family history, sodium intake, history of diabetes mellitus, smoking habit, alcohol and caffeine consumption, potassium intake, calcium intake, low magnesium, and stress events are not collected. Further study is needed to evaluate these factors thoroughly.

In conclusion, this study has shown a significant relationship between overweight and hypertension in the elderly living in Hegarmanah. Nutritional status maintenance is needed to control of hypertension through health promotion. Therefore, blood pressure measurement, bodyweight measurement, and regular hypertension therapy are necessary for the elderly.

\section{References}

1. Setiawan Z. Prevalensi dan determinan hipertensi di Pulau Jawa tahun 2004. Kesmas. 2006;1(2):57-62.

2. McCance K,L Huether SE, Brashers VL, Rote NS.. Pathophysiology: the biologic basis for disease in adults and children. 6thed . Maryland Heights: Mosby Elsevier; 2010. p. 1149-50. 
3. Williams B, Poulter NR, Brown MJ, Davis M, McInnes GT, Potter JF, et al. British Hypertension Society guidelines for hypertension management 2004 (BHS-IV): summary. BMJ. 2004;328(7440):634-40.

4. Rahajeng E, Tuminah S. Prevalensi hipertensi dan determinannya di Indonesia. Maj Kedokt Indon. 2009;59(12):580-7.

5. Pratiwi VR, Tala ZZ. Gambaran status gizi pasien hipertensi lansia di RSUP H.Adam Malik Medan. e-Jurnal FK USU. 2013;1(1):1-5.

6. Mitchell GF, Parise H, Benjamin EJ, Larson MG, Keyes MJ, Vita JA, et al. Changes in arterial stiffness and wave reflection with advancing age in healthy men and women: the Framingham Heart Study. Hypertension. 2004;43(6):1239-45.

7. Kamso S, Rumawas JS, Lukito W,
Purwantyastuti. Determinants of blood pressure among Indonesian elderly individuals who are of normal and overweight: a cross sectional study in an urban population. Asia Pac J Clin Nutr. 2007;16(3):546-53.

8. Aizawa-Abe M, Ogawa Y, Masuzaki $\mathrm{H}$, Ebihara $\mathrm{K}$, Satoh N, Iwai $\mathrm{H}$, et al. Pathophysiological role of leptin in obesity-related hypertension. J Clin Invest. 2000;105(9):1243-52.

9. Beltowski J. Role of leptin in blood pressure regulation and arterial hypertension. J Hypertens. 2006;24(5):789-801.

10. Wen CP, David Cheng TY, Tsai SP, Chan HT, Hsu HL, Hsu CC, et al. Are Asians at greater mortality risks for being overweight than aucasians? Redefining obesity for Asians. Public Health Nutr. 2009;12(4):497-506. 